\title{
An Orthologue of the Retinoic Acid Receptor (RAR) Is Present in the Ecdysozoa Phylum Priapulida
}

\author{
Elza S. S. Fonseca ${ }^{1,2,+}\left(\mathbb{D}\right.$, Youhei Hiromori ${ }^{3,4,+}$, Yoshifumi Kaite ${ }^{3}$, Raquel Ruivo ${ }^{1}{ }^{1}$, \\ João N. Franco ${ }^{1}\left(\mathbb{D}\right.$, Tsuyoshi Nakanishi ${ }^{3, *}$, Miguel M. Santos ${ }^{1,2, *}$ and L. Filipe C. Castro ${ }^{1,2, *}$ \\ 1 CIIMAR/CIMAR Interdisciplinary Centre of Marine and Environmental Research, U.Porto, 4450-208 \\ Matosinhos, Portugal; fonseca.ess@gmail.com (E.S.S.F.); ruivo.raquel@gmail.com (R.R.); \\ joaonunofranco@gmail.com (J.N.F.) \\ 2 FCUP-Faculty of Sciences, Department of Biology, U.Porto, 4169-007 Porto, Portugal \\ 3 Laboratory of Hygienic Chemistry and Molecular Toxicology, Gifu Pharmaceutical University, Gifu 501-1196, \\ Japan; hayake5@hotmail.com (Y.H.); 135018@gifu-pu.ac.jp (Y.K.) \\ 4 Faculty of Pharmaceutical Sciences, Suzuka University of Medical Science, Suzuka 513-8670, Japan \\ * Correspondence: nakanishi@gifu-pu.ac.jp (T.N.); santos@ciimar.up.pt (M.M.S.); \\ filipe.castro@ciimar.up.pt (L.F.C.C.) \\ + These authors contributed equally to this work.
}

Received: 18 October 2019; Accepted: 27 November 2019; Published: 29 November 2019

\begin{abstract}
Signalling molecules and their cognate receptors are central components of the Metazoa endocrine system. Defining their presence or absence in extant animal lineages is critical to accurately devise evolutionary patterns, physiological shifts and the impact of endocrine disrupting chemicals. Here, we address the evolution of retinoic acid (RA) signalling in the Priapulida worm, Priapulus caudatus Lamarck, 1816, an Ecdysozoa. RA signalling has been shown to be central to chordate endocrine homeostasis, participating in multiple developmental and physiological processes. Priapulids, with their slow rate of molecular evolution and phylogenetic position, represent a key taxon to investigate the early phases of Ecdysozoa evolution. By exploring a draft genome assembly, we show, by means of phylogenetics and functional assays, that an orthologue of the nuclear receptor retinoic acid receptor (RAR) subfamily, a central mediator of RA signalling, is present in Ecdysozoa, contrary to previous perception. We further demonstrate that the Priapulida RAR displays low-affinity for retinoids (similar to annelids), and is not responsive to common endocrine disruptors acting via RAR. Our findings provide a timeline for RA signalling evolution in the Bilateria and give support to the hypothesis that the increase in RA affinity towards RAR is a late acquisition in the evolution of the Metazoa.
\end{abstract}

Keywords: Bilateria; nuclear receptors; xenobiotics; endocrine system

\section{Introduction}

Retinoic acid (RA) is a critical regulator of multiple biological processes in vertebrates including cell differentiation and embryonic development [1,2], central nervous system development [3-5], organ formation and tissue maintenance [6-8] and vision [9]. Retinoids, such all-trans retinoic acid (ATRA), 9-cis retinoic acid (9cisRA) and 13-cis retinoic acid (13cisRA) are active metabolites of vitamin A (retinol), known to bind and modulate the retinoic acid receptor (RAR) and retinoid $X$ receptor (RXR), the central mediators of RA signalling [10]. RAR and RXR belong to the nuclear receptor (NR) superfamily and are ligand-dependent transcription factors that regulate the expression of specific genes [11,12]. RAR heterodimerizes with RXR and recognizes specific RA responsive elements (RAREs) in the regulatory region of the target gene $[13,14]$. Upon binding to ligands, the position of the helix 
12 on the ligand-binding domain (LBD) is modified, allowing the recruitment of coactivators and consequently, the activation of gene transcription $[11,13,14]$. The emergence of various non-chordate genome sequences established that RA signalling is not chordate-specific, since signalling components such as RAR and RXR gene orthologues have been found in species from Ambulacraria (echinoderms and hemichordates) [15-20]. Recently, RAR was also functionally characterized in various mollusc species and in a second Lophotrochozoa clade, the annelid worm Platynereis dumerilii. Yet, functional studies in mollusc species demonstrated the loss of RA binding affinity towards RAR [21-24]. In contrast, the annelid Platynereis RAR orthologue showed a conserved capacity to bind and respond to retinoids, but with lower affinity compared to vertebrate RAR paralogues [25]. Furthermore, it was demonstrated that RAs trigger neuronal differentiation, a role previously described only in chordates $[4,21,26]$. Surprisingly, in a second annelid species, Helobdella robusta (leech), RAR and other RA signaling components are absent [15]. The search for RAR gene orthologues in Ecdysozoa (e.g., arthropods and nematodes) genomes was previously unsuccessful, implying that $R A R$ was probably lost in this superphylum [15]. Overall, these studies suggest that 1) $R A R$ evolution was shaped by events of secondary gene loss during Bilateria evolution, notably in the whole Ecdysozoa lineage and Appendicularia (Tunicata) $[15,16,18]$ and 2) the bilaterian $R A R$ ancestor was a RA low-affinity sensor, with the ability to bind retinoids and activate transcription of target genes-annelids (Platynereis), or a receptor without capacity to bind ligands as seen in molluscs [22-25]. Additionally, NRs are prime targets of endocrine disrupting chemicals (EDCs) (e.g., [27]), with various examples denoting the impact of EDCs acting via NRs [28,29]. Yet, variations in NR gene complement and sequence variation as well as the molecular architecture of endocrine systems are of paramount importance to recognize the mechanisms of action of EDCs [30,31], particularly in invertebrate lineages, e.g., [32,33]. In the specific case of $R A R$, environmental contaminants such as pesticides have been shown to exploit mammalian RARs [34], but not the molluscan orthologue [24]. To further scrutinize the evolution RA signalling, specifically if $R A R$ is absent or present in other extant Ecdysozoa lineages, we investigated the genome of the penis worm, Priapulus caudatus Lamarck, 1816 (Scalidophora, Priapulida). Priapulids are mud-dwelling, carnivorous marine worms with a tubular body shape and an eversible proboscis (Figure 1A; see Video S1) that altered little since the arthropod/priapulid common ancestor (over 520 million years ago) [35-37]. Their morphological and developmental characteristics together with their slow rate of molecular evolution suggest Priapulida as a key phylum to understand the evolution of Ecdysozoa. 


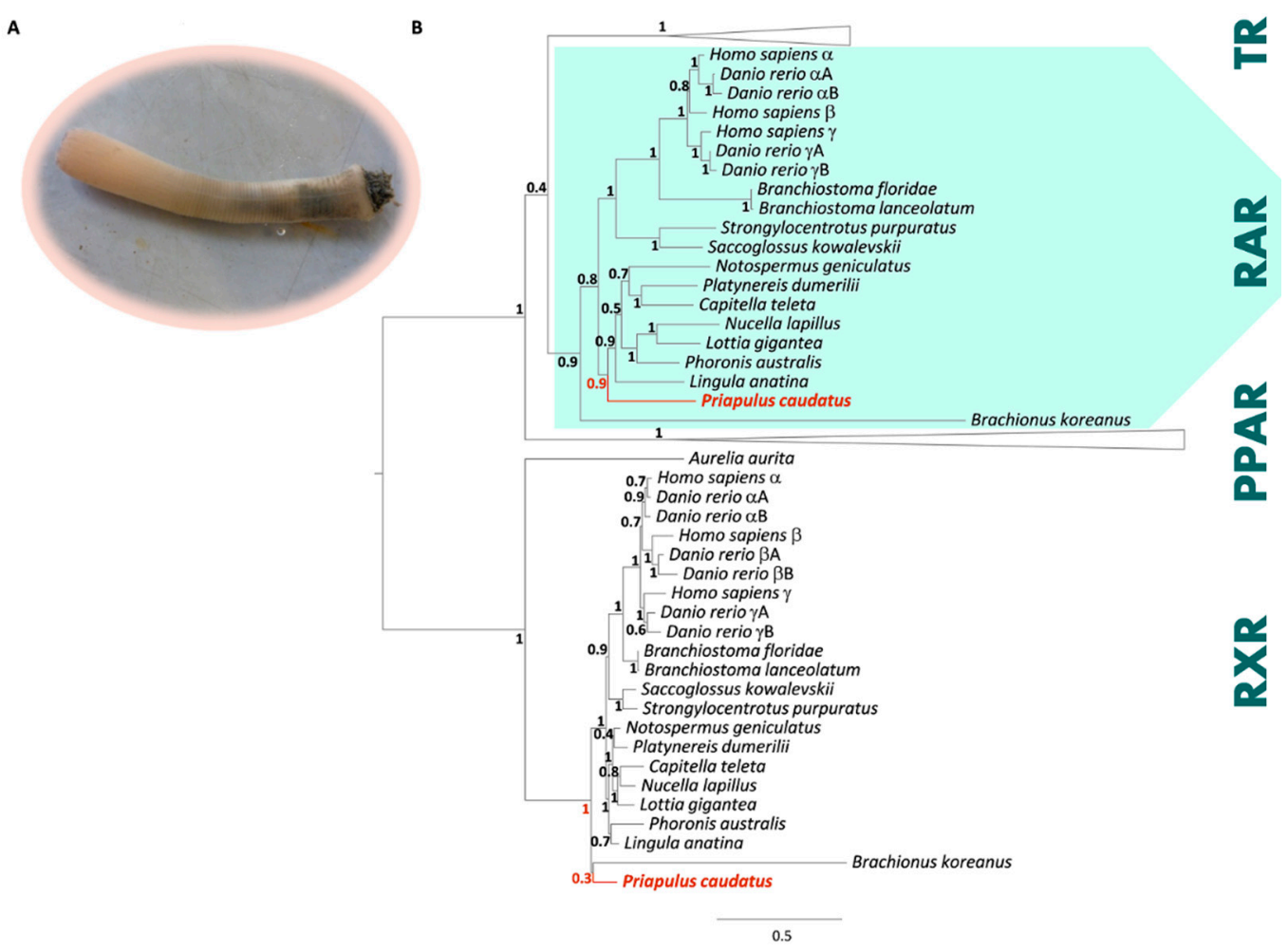

Figure 1. The retinoic acid receptor (RAR) and retinoid $X$ receptor (RXR) nuclear receptors of $P$. caudatus. (A) A specimen photograph of P. caudatus. (B) Maximum likelihood phylogenetic tree of RAR, $\mathrm{RXR}$, thyroid hormone receptor (TR) and peroxisome proliferator-activated receptor (PPAR) nuclear receptors; numbers at nodes indicate posterior probabilities calculated using aBayes. Photograph by João N. Franco.

\section{Materials and Methods}

\subsection{Sampling}

One adult and two juvenile specimens of P. caudatus were collected at the Gullmarn fjord, Sweden, and preserved on RNA later (Invitrogen, Carlsbad, CA, USA) for further total RNA extraction.

\subsection{RNA Extraction}

The adult priapulid was dissected into small portions and homogenized with PureZOL RNA Isolation Reagent ${ }^{\circledR}$ (Bio-Rad, Hercules, CA, USA). The extraction of nucleic acids was performed with chloroform according to the manufacturer's instructions and the resulting aqueous phase was used to isolate the total RNA. The illustra RNAspin Mini RNA Isolation (GE Healthcare, Chicago, IL, USA) kit was used for total RNA isolation. A step of on-column DNAse I digestion was included to exclude genomic contamination and the RNA was eluted with RNase-free water, starting from the ethanol step. The iScript ${ }^{\mathrm{TM}} \mathrm{CDNA}$ Synthesis Kit (Bio-Rad, Hercules, CA, USA) was used for cDNA synthesis and performed according to the manufacturer's recommendations, using $1000 \mathrm{ng}$ of the RNA previously isolated.

\subsection{RXR and RAR Gene Isolation}

A BLAST approach conducted on the publicly available $P$. caudatus draft genome (GCA_000485595.2, Priapulus_caudatus-5.0.1) to investigate the presence of RAR and RXR-like sequences. The open reading frame (ORF) of $P$. caudatus $R A R$ and $R X R$ were deduced from the genome assembly and isolated using a polymerase chain reaction (PCR) with specific primers (Table S1). In the case of $R X R$, two partial nucleotide sequences were used to design specific primers (Table $\mathrm{S} 1$ ) 
and a partial P. caudatus RXR containing the termination codon was isolated by PCR. To obtain the remaining sequence, the partial $R X R$ isolated sequence was extended using the SMARTerTM RACE cDNA Amplification Kit (Clontech, Mountain View, CA, USA) following the manufacturer instructions, using specific RACE PCR primers (Table S1). The Phusion Flash High-Fidelity PCR Master Mix (ThermoFisher, Waltham, MA, USA) was used in all PCR reactions and the obtained products were purified with NZYGelpure (Nzytech, Lisbon, Portugal), cloned into pGEM-T Easy Vector System (Promega, Madison, WI, USA). The sequences were confirmed by automated Sanger sequencing (Eurofins GATC). RAR and RXR P. caudatus sequences have been deposited in GenBank (Accession numbers MK780070 and MK780071, respectively).

\subsection{Sequence and Phylogenetic Analysis}

Amino acid sequences of RAR, RXR, thyroid hormone receptor (TR) and peroxisome proliferator-activated receptor (PPAR) from various Metazoa taxonomic groups were recovered through BLASTp searches in GenBank, Joint Genome Institute (JGI) Genome Portal and Okinawa Institute of Science and Technology (OIST) Marine Genomics Unit Genome Browser. Retrieved sequences and corresponding protein accession numbers are listed in the Supplementary material Table S2. The collected sequences were aligned with the Multiple Alignment using Fast Fourier Transform (MAFFT) programme v7 (L-INS-i method) [38], visualized and edited in Geneious ${ }^{\circledR}$ v7.1.7. Based on previous studies [25,39-42], the amino acids residues that interact with ATRA were identified. The columns containing gaps were stripped, resulting in a final alignment contained 71 sequences and 277 positions. A Maximum Likelihood phylogenetic analysis was performed using the PhyML 3.0 server with the amino acid substitution model LG + G + I and the evolutionary model automatically selected [43]. The branch support for phylogenetic trees was calculated using aBayes. FigTree v1.3.1 was used to visualize the tree.

\subsection{Construction of Plasmid Vectors}

The hinge region and LBD of RAR and RXR were isolated from human and penis worm by PCR with specific primers (Table S3) and cloned into pBIND and/or pACT vectors (Promega, accession numbers AF264722 and AF264723.1), to produce "chimeric" receptors with the yeast transcriptional activator GAL4 (RAR-LBD-GAL4) or the viral enhancer, VP16 (RXR-LBD-VP16), which acts on proximal downstream promoters, respectively $[44,45]$. The priapulid RAR LBD was amplified by PCR from pGEM-pCauRAR with specific primer (FP: 5'-ACTGGATCCTCGATTATGTCTATGCAACAGCGA-3', RP: $5^{\prime}$-GATTCTAGAACTAGTGATTTCACGGTATGCAG-3') and the product was digested with BamHI and XbaI. The digested fragment was subcloned into BamHI-XbaI site of pCold-TF vector (TAKARA bio, accession number AB213654), for the priapulid RAR LBD-His6-tagged trigger factor hybrid protein. Plasmid sequences were confirmed using automated Sanger sequencing (Eurofins GATC). The human RAR $\alpha$ LBD was previously cloned into pGEX-4T-1 vector (GE Healthcare Life Sciences, accession number U13853), for the human RAR $\alpha$ LBD-Glutathione S-transferase hybrid protein [22].

\subsection{Chemicals and Solutions}

ATRA, 9cisRA, 13cisRA, endrin, dieldrin, and sterile Dimethyl sulfoxide (DMSO) were purchased from Sigma-Aldrich (St. Louis, MO, USA). The stock solutions were prepared in DMSO: ATRA, 9cisRA and 13cisRA at $0.1,1$ and $10 \mathrm{mM}$, endrin and dieldrin at $10 \mathrm{mM}$.

\subsection{Cell Culture and Transactivation Assays}

Cos-1 cells were maintained in Dulbecco's Modified Eagle Medium (DMEM) (PAN-Biotech, Aidenbach, Bayern, Germany). A supplementation with 10\% fetal bovine serum (PAN-Biotech, Aidenbach, Bayern, Germany) and 1\% penicillin/streptomycin (PAN-Biotech, Aidenbach, Bayern, Germany)) was used. Cells were maintained at $37{ }^{\circ} \mathrm{C}$ with a humidified atmosphere and $5 \% \mathrm{CO}_{2}$. Cells were seeded in 24-well culture plates at a density of $2 \times 10^{5}$ live cells/well and after $24 \mathrm{~h}$, transfected with 
$0.5 \mu \mathrm{g}$ of pBIND constructs (pBIND-PcauRAR-LBD or pBIND-HsaRAR $\gamma$-LBD (positive control)) and 1 $\mu \mathrm{g}$ of pGL4.31 luciferase reporter vector (DQ487213; Promega), containing five upstream activation sequence (UAS) elements, upstream of the firefly luciferase reporter gene or, in the case of heterodimer transfection assays, with $0.5 \mu \mathrm{g}$ of pBIND constructs (pBIND-PcauRAR-LBD or pBIND-HsaRAR $\gamma$-LBD), $0.5 \mu \mathrm{g}$ pACT constructs (pACT-PcauRXR-LBD or pACT-HsaRXR $\gamma$-LBD (positive control)) and 0.5 $\mu \mathrm{g}$ of pGL4.31, using lipofectamine 2000 reagent (Invitrogen) in Opti-MEM (Gibco, Carlsbad, CA, USA), to a final volume of $350 \mu \mathrm{L}$. After $5 \mathrm{~h}$ of incubation, transfection media was replaced by DMEM phenol-free supplemented with 10\% dextran-coated charcoal-treated serum (Invitrogen) and $1 \%$ penicillin/streptomycin (Invitrogen) containing the test compounds. Final concentrations were the following: $0.1,1$ and $10 \mu \mathrm{M}$ ATRA, 9cisRA or 13cisRA and $10 \mu \mathrm{M}$ organochlorine pesticides (endrin and dieldrin) dissolved in DMSO (0.1\%). Cells were lysed $24 \mathrm{~h}$ after transfection. Firefly luciferase (reporter pGL4.31) and Renilla luciferase (pBIND) activities were assayed with Dual-Luciferase Reporter Assay System (Promega, Madison, WI, USA), according to the manufacturer's instructions. Two technical replicates per condition in three independent assays were performed for all transfections. The results were expressed as fold-induction resulting from the ratio between luciferase (reporter pGL4.31) and Renilla (internal control for transfection efficiency luminescent activity), and then normalized by the DMSO control. Transactivation data was calculated as means of the normalized values $(n=3)$ and the bars with standard error of the mean (SEM) from the three separate experiments. The means of the technical replicates were used for statistical analysis with one-way ANOVA, followed by Holm-Sidak method in the SigmaPlot software v11.0. Data were transformed whenever the normality failed. The level of significance was set to 0.05 .

\subsection{Ligand Binding Assays}

The PcauRAR LBD-His6-tagged trigger factor hybrid protein was expressed in Escherichia coli BL21 (DE3) cells containing the chaperon plasmid pG-Tf2 (Takara bio, Kusatsu, Shiga, Japan) and purified by using His-select nickel affinity gel (Sigma-Aldrich, St. Louis, MO, USA). The HsaRAR $\alpha$ LBD-Glutathione S-transferase hybrid protein was expressed in Escherichia coli BL21 (DE3) cells and purified by Glutathione Sepharose 4B (GE Healthcare, Chicago, IL, USA) (positive control). Ligand binding assay was assessed as previously described [22,46-48]. In brief, the purified protein (12.5 $\mu \mathrm{g} / \mathrm{mL})$ was incubated with $10 \mathrm{nM}$ of all-trans retinoic acid $\left(11,12-{ }^{3} \mathrm{H}\right)\left(\left[{ }^{3} \mathrm{H}\right] \mathrm{ATRA} ; 1.665 \mathrm{TBq} / \mathrm{mmol}\right.$; Amersham Biosciences) or $10 \mathrm{nM}$ of Retinoic Acid, $\left(11,12-{ }^{3} \mathrm{H}\right)$ 9-cis $\left(\left[{ }^{3} \mathrm{H}\right]\right.$ 9cisRA; $1.95 \mathrm{TBq} / \mathrm{mmol}$; PerkinElmer). Unlabeled ATRA and 9cisRA were used to compete for $\left[{ }^{3} \mathrm{H}\right]$ ATRA or $\left[{ }^{3} \mathrm{H}\right]$ 9cisRA in this assay to determine the binding preferences of PcauRAR LBD or HsaRAR $\alpha$ LBD. Hydroxyapatite was added to precipitate the receptor protein and bound radioactive compounds after an incubation step at $4{ }^{\circ} \mathrm{C}$ for $1 \mathrm{~h}$. The hydroxyapatite pellet was washed. The radioactivity in the pellet was determined by liquid scintillation counting.

\section{Results}

\subsection{Phylogenetic and Sequence Analysis of Priapulid RAR}

By thoroughly examining a genome draft of $P$. caudatus, we established the presence of sequences with high similarity to $R A R$ and $R X R$ respectively. Since $R A R$ sequences are absent from previously analysed Ecdysozoa genomes, we went on to validate this initial screening. We experimentally isolated the full-length sequences of both $R A R$ and $R X R$ from $P$. caudatus cDNA. These encode two protein sequences with 491 (RAR) and 404 (RXR) amino acids. To determine the orthology of the isolated sequence a phylogenetic analysis was conducted (Figure 1B), including RAR, RXR, TR and PPAR amino acid sequences of vertebrates (human and zebrafish), cephalochordates (Florida and European lancelet), ambulacrarians (acorn worm and purple sea urchin), molluscs (Atlantic dogwhelk and owl limpet), annelids (Dumeril's clam worm and polychaete worm), a nemertean (ribbon worm), a 
phoronid (phoronid worm), a brachiopod (common Oriental lamp shell), a rotifer (Korean monogonont rotifer), and a cnidarian (moon jelly).

The predicted RAR (PcauRAR) and RXR (PcauRXR) sequences of the priapulid worm robustly clustered in the respective clade (Figure $1 B$ ). Next, we examined the amino acid sequence alignment with PcauRAR (Figure 2), which revealed that, similarly to other RARs, PcauRAR has a conserved modular structure typical of NRs, with a conserved DNA- binding domain (DBD) and a moderately conserved LBD [49]. The PcauRAR-DBD shares approximately 80-82\% of sequence identity with human and molluscs RARs, 84\% with annelids RARs, 81-87\% with nemertean, brachiopod and phoronid RARs, and 78\% with rotifer RAR. Regarding the PcauRAR-LBD, the identity with human RARs decreases to 39-41\%, with molluscs RARs to 47-49\%, with annelids, nemertean and brachiopod RARs to $49-54 \%$, and with phoronid and rotifer RARs to only $33 \%$ and $20 \%$ respectively (Figure 2).

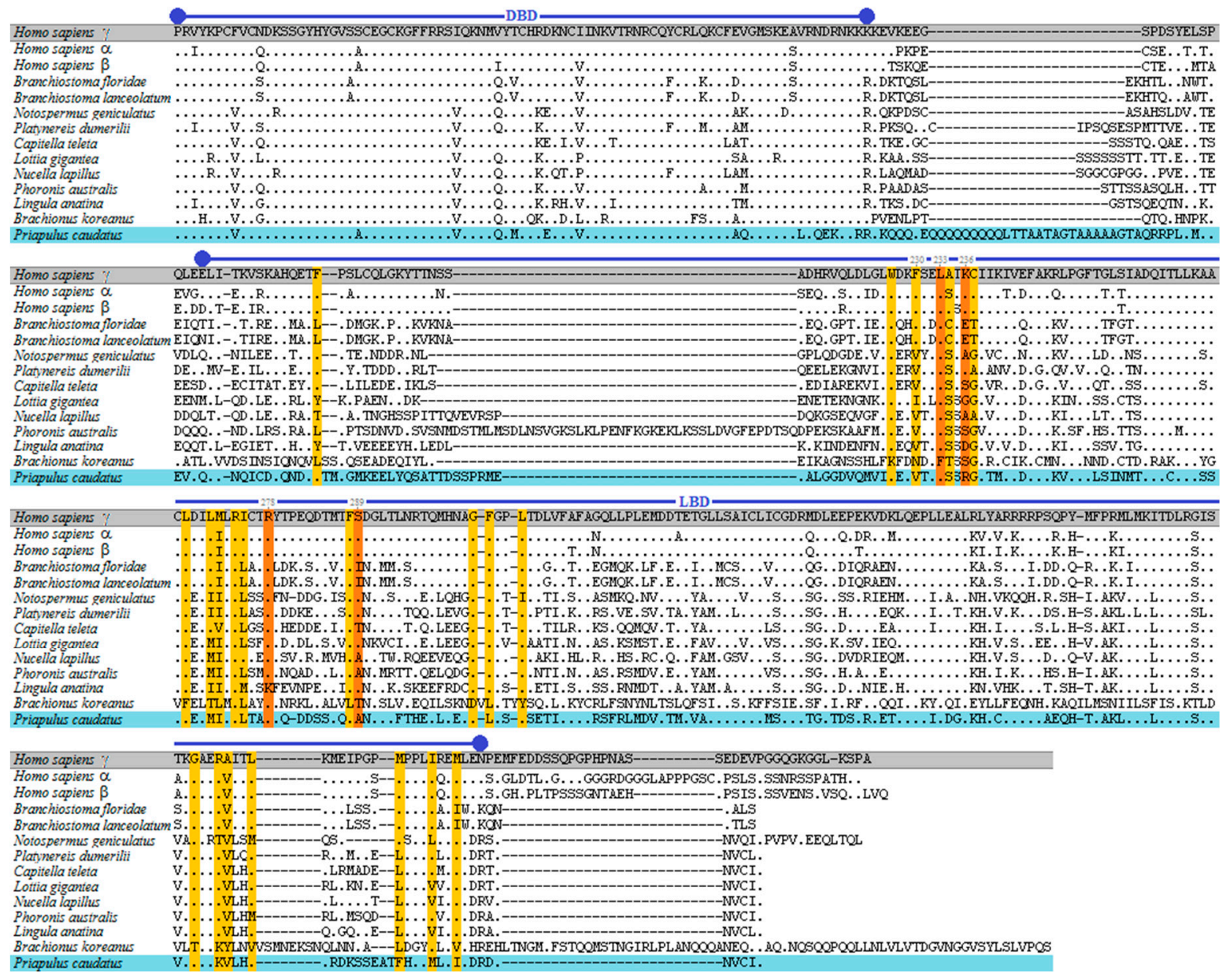

Figure 2. Amino acid sequence alignment of the RAR DNA- and ligand- binding domains from human, lancelets, molluscs, annelids, nemertean, brachiopod, phoronid, rotifer and priapulid RAR protein sequences. Key amino acid residues that interact with ATRA in the human RAR $\gamma$ ligand-binging pocket (LBP) are highlighted: orange - direct or indirect hydrogen bonds, yellow-hydrophobic and Van der Waals interactions [25,39-42]. The DBD and LBD are delimited by the upper blue lines.

Analysis of the key amino acid residues known to interact with ATRA in human RAR $\gamma$ (Hsa RAR $\gamma$ ) ligand binding pocket (LBP) [39,42], showed that 14 out of 25 are different (Figure 2), a feature also observed in previous studies: 9 to 11 amino acids in mollusc [24] and 8 in annelids [25]. In nemertean 12 amino acids are not conserved, and, similarly to molluscs, 9 amino acids are not conserved in brachiopod and phoronid. In rotifer only 3 of the key 25 amino acids are conserved. Regarding these 25 amino acids residues, 4 (Leu233, Lys236, Arg278, and Ser289) participate in stable hydrogen bonds with 
the carboxyl group of ATRA in HsaRAR $\gamma$. In PcauRAR, as well as, in phoronid and brachiopod RARs, two of these residues are not conserved (Lys236>Arg, Ser, Asp in priapulid, phoronid, brachiopod; Arg278 > Lys in brachiopod; and Ser289 > Ala in priapulid and phoronid), and only one in nemertean RAR (Lys236>Arg), whereas in the annelid RAR they are all conserved (Figure 2). Furthermore, the Phe230 residue which was demonstrated to play a crucial role for RA binding, enabling transactivation properties [39], is replaced by a Val residue among lophotrochozoans and priapulid. The mutation to a Phe in Platynereis results on a decreased ability of the annelid RAR to activate transcription upon binding to ATRA [25], suggesting a similar consequence for priapulid.

\subsection{Functional Characterization of the Priapulid RAR Orthologue}

To unfold the binding properties of PcauRAR and compare with both mollusc and annelid RARs, we next investigated the binding profile of the priapulid orthologue to transactivate target gene transcription, performing transactivation assays with GAL4-LBD chimeric receptors. Thus, we tested the ability of PcauRAR-LBD-GAL4 to bind retinoids (ATRA, 9cisRA and 13cisRA) and to activate a luciferase reporter gene (Figure 3). Our results show that PcauRAR is able to significantly $(P<0.05)$ activate transcription upon binding to retinoids at concentrations of 1 and $10 \mu \mathrm{M}$ (Figure 3B), but at a lesser degree than HsaRAR $\gamma$ (Figure 3A). The results obtained with transactivation assays were next confirmed by a competitive ligand binding assay. The ability of PcauRAR to bind to ATRA and 9cisRA was clearly demonstrated (Figure 4).
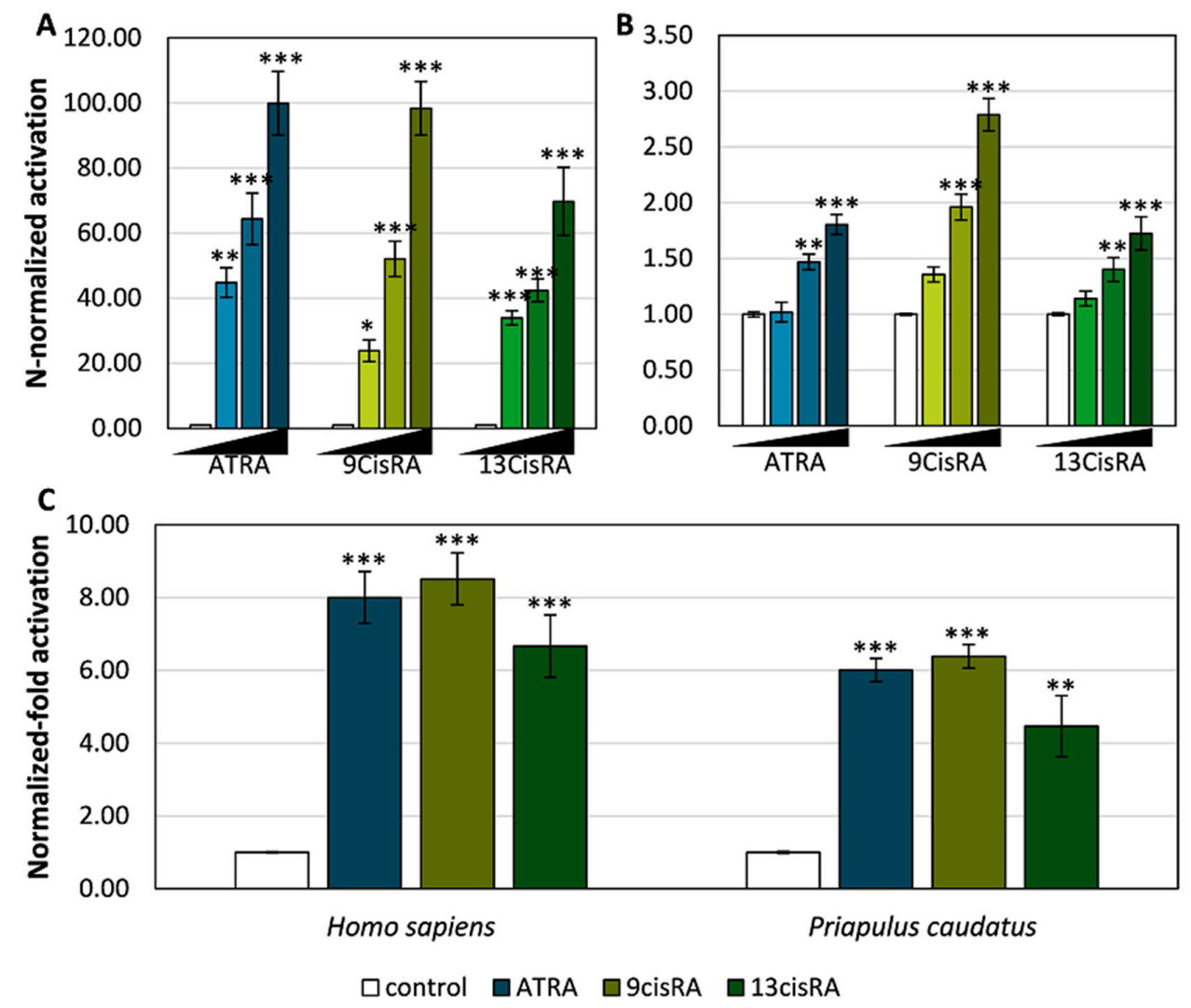

Figure 3. Luciferase transcription transactivation mediated by chimeric receptors in the presence of various ligands (ATRA, 9cisRA or 13cisRA at a final concentration of 0.1,1 and $10 \mu \mathrm{M}$ ). (A) Human RAR-LBD-GAL4; (B) Priapulid RAR-LBD-GAL4; (C) Human and priapulid RAR/RXR heterodimers. Data represent means \pm SEM from three separate experiments $(n=3)$. The results were normalized to the control condition (DMSO without ligand). Significant differences between the tested concentrations and the solvent control were inferred using one-way ANOVA. Asterisks denote significant differences ( $\left.P<0.05,{ }^{* *} P<0.01,{ }^{* * *} P<0.001\right)$ between the tested compound and the control. 
A [ $\left.{ }^{3} \mathrm{H}\right]$ ATRA vs unlabeled ATRA

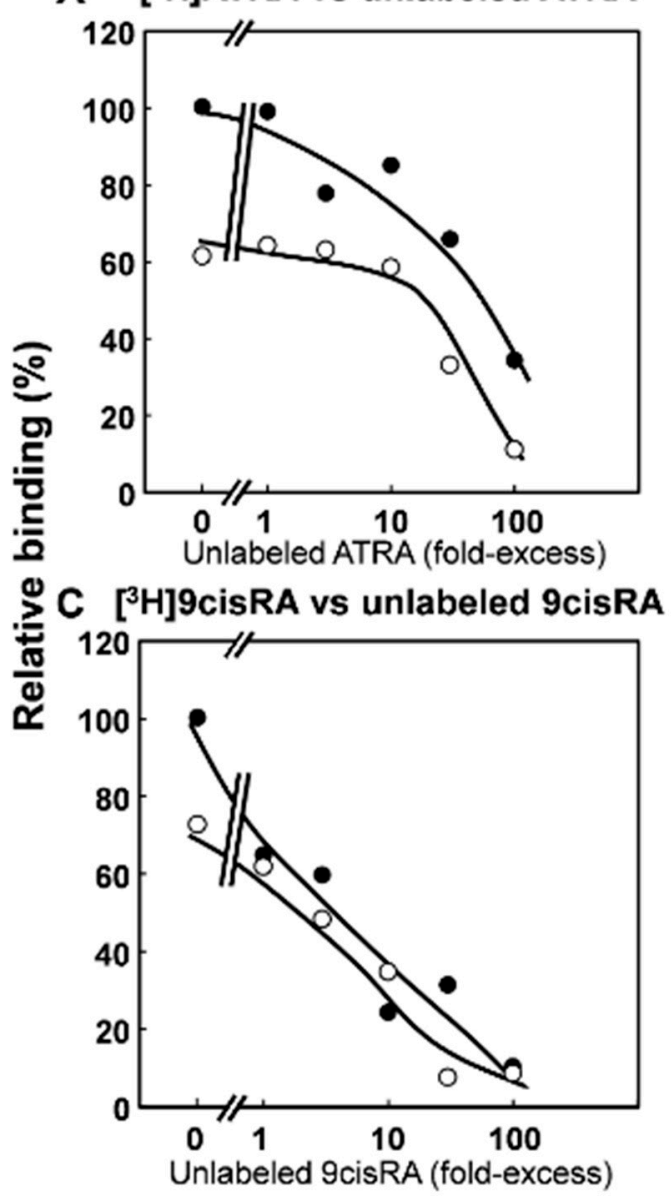

B [ $\left.{ }^{3} \mathrm{H}\right]$ ATRA vs unlabeled 9cisRA

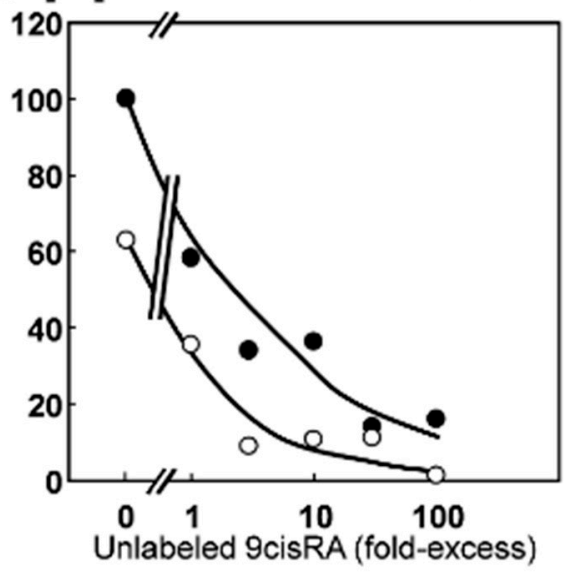

OPcauRAR

- HsaRAR $\alpha$

Figure 4. Competition by ATRA and 9cisRA with $\left[{ }^{3} \mathrm{H}\right] \mathrm{ATRA}$ and $\left[{ }^{3} \mathrm{H}\right] 9$ cisRA for binding to the LBD of PcauRAR and HsaRAR $\alpha$. The LBD of PcauRAR $(\bigcirc)$ and HsaRAR $\alpha$ protein $(\bullet)$ was incubated with increasing concentrations of unlabeled ATRA $(\mathbf{A})$ or 9cisRA $(\mathbf{B}, \mathbf{C})$ as competitors in the presence of $\left[{ }^{3} \mathrm{H}\right]$ ATRA $(\mathbf{A}, \mathbf{B})$ or $\left[{ }^{3} \mathrm{H}\right]$ ccisRA $(\mathbf{C})$ as ligand. Specific binding of the radio ligands was defined as total binding minus that occurring in the presence of 1000 -fold molar excess of unlabeled ATRA (A,B) or 9cisRA (C). Results were expressed as percentage of specific binding of the radio ligands. The binding of each radio ligand to HsaRAR $\alpha$ in the absence of unlabeled competitors was set at $100 \%$. Each experiment was performed at least twice, and representative curves are shown.

In vertebrates, RAR dimerizes with RXR $[13,14,50]$. Thus, we next assayed the capacity of RAR to transactivate luciferase transcription as a heterodimer with RXR, using a two-hybrid protein-protein interaction strategy ( $\mathrm{pBind} / \mathrm{pACT}$ system). The interaction between the chimeric proteins (RAR-LBD-GAL4 and RXR-LBD-VP16) was first verified (Supplementary material Figure S1) and then, the activation of the heterodimer was tested with ATRA, 9cisRA and 13cisRA at $10 \mu \mathrm{M}$ (Figure 3C). As predicted, the RAR/RXR heterodimer activates luciferase transcription upon binding to the tested retinoids $(P<0.05)$ in both human and priapulid (Figure $3 C$ ).

\subsection{Pesticides Do Not Activate Transcription via the Priapulid RAR}

NRs are classical targets of endocrine disrupting chemicals [51-53]. RARs in particular have been shown to bind and activate transcription in the presence of specific toxicants [34,54]. To address whether two organochlorine pesticides (endrin and dieldrin) known as endocrine disruptive chemicals (EDCs) acting via human RARs are also binding to PcauRAR, we performed transactivation assays. Importantly, these pesticides are persistent in fishes and sediments from the Baltic Sea, where P. caudatus 
occurs [55-58]. As previously shown with mollusc RARs [24], these EDCs were unable to promote luciferase transcription through PcauRAR activation $(P>0.05)$ (Figure 5).

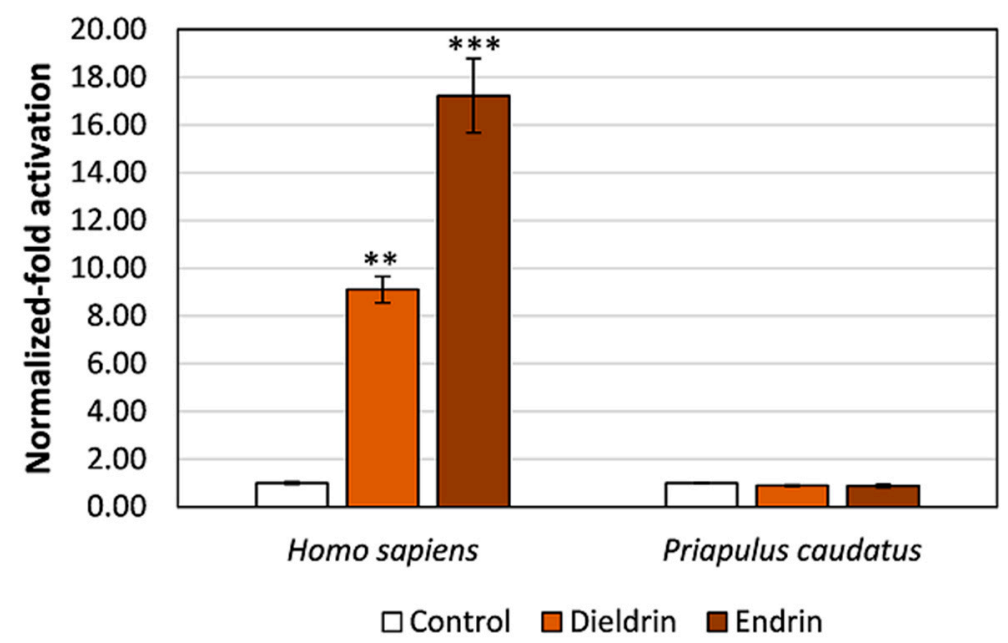

Figure 5. Luciferase transcription transactivation mediated by human and priapulid chimeric receptors (RAR-LBD-GAL4) in the presence of $10 \mu \mathrm{M}$ endrin or dieldrin (organochlorine pesticides). Data represent means \pm SEM from three separate experiments $(n=3)$. The results were normalized to the control condition (DMSO without ligand). Significant differences between the tested concentrations and the solvent control were inferred using one-way ANOVA. Asterisks denote significant differences (** $\left.P<0.01,{ }^{* * *} P<0.001\right)$ between the tested compound and the control.

\section{Discussion}

The emergence of non-chordate sequenced genomes has significantly modified the evolutionary consensus of RA signalling as a chordate-specific feature. In effect, $R A R$ and other RA signalling components were described in non-chordate metazoans, such as ambulacrarians (echinoderms and hemichordates) [16] and lophotrochozoans (molluscs and annelids) [21-25]. Strikingly, we establish that a retinoid-activated $R A R$ was retained in the Ecdysozoa P. caudatus. Our findings strongly support earlier studies, suggesting that $R A R$ originated in the Bilateria ancestor [22,24,25], and substantiate the likely loss of this transcription factor in most lineages leading to extant Ecdysozoa species examined so far (Figure 6). Together, these results emphasize the importance of Priapulida to decipher Ecdysozoa evolution, in particular that of NR biology [35,59].

By inspecting a RAR protein sequence alignment, we show that the penis worm orthologue exhibits the characteristic modular structure of NRs and displays a higher sequence homology with annelid RARs than with mollusc and vertebrate RARs. The retinoid binding profile of PcauRAR was corroborated with both transactivation assays and a competitive ligand binding assay that clearly established the ability of PcauRAR to bind to ATRA and 9cisRA, as it had been previously demonstrated with the annelid $R A R$ [25], but not in molluscs [22-24]. Yet, our findings consistently show that PcauRAR exhibits a low affinity for the tested ligands (retinoids) - in the micromolar range, similar to previous findings for the Platynereis RAR orthologue [25]. This is in stark contrast with the affinity shown by chordate orthologues (nanomolar scale). In effect, the operating mode of PcauRAR in the presence of retinoids (ATRA, 9cisRA and 13cisRA) significantly induced luciferase transcription via PcauRAR activation, but at lower levels than HsaRAR $\gamma$, as suggested by the LBP composition. Previous studies with crystallographic analysis of human RAR $\gamma$ [39] and Platynereis RAR [25] in complex with ATRA revealed a strong divergence in the structural interaction on how ATRA binds the RAR LBP residues in these species. In human RARs, 25 amino acid residues are crucial for the interaction with ATRA, with 4 of these residues forming direct or indirect hydrogen bonds with the carboxyl group of retinoids [39,42]. Despite the conservation of these 4 residues, the interaction of retinoids with annelid RAR-LBP is dominated by loose van der Waals forces and no hydrogen bond with retinoid carboxyl 
group have been described [25]. Thus, given the similarities of annelid and priapulid RAR sequences and ligand affinities, we anticipate an annelid-RAR-like structural interaction between ATRA and the priapulid RAR-LBP. A similar outcome is also expected for the RAR orthologues from nemertean, brachiopod and phoronid. Moreover, while in Platynereis ATRA displays a higher capacity to activate transcription via $R A R$, we find a similar pattern but for 9cisRA. Interestingly, 9cisRA was not detected in Platynereis tissues [25] and, at present, RA levels are unknown in priapulids. Furthermore, we did not explore the possibility of other endogenous and uncharacterized ligands to bind and activate transcription via RAR in priapulids, although this possibility should deserve future investigation. Overall, it remains a tantalizing question of the exact in vivo functions of PcauRAR and whether these are conserved between annelids and priapulids (and other protostomes). Additionally, the finding of RAR in Priapulida raises the interesting possibility that other RA signalling and metabolic components might be present in other protostome phyla such as Loricifera and Bryozoa. Future studies should be undertaken to firmly explore these hypotheses.

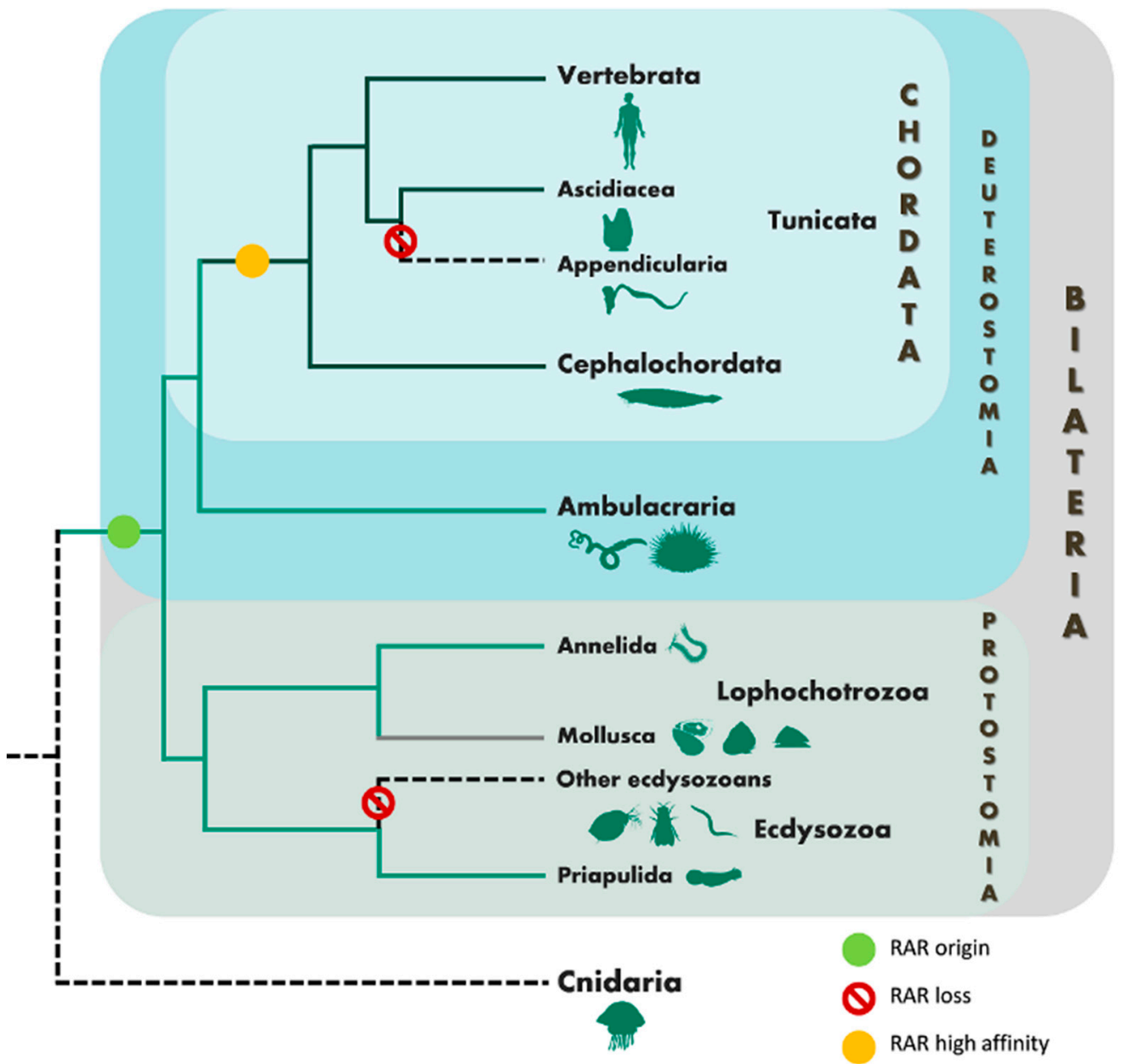

Figure 6. The evolution of RAR in Metazoa lineages. Black dashed lines represent no RAR known, light green full lines represent RA low-affinity sensors, dark green full lines represent RA high-affinity receptors, grey full line represent RA unresponsive sensors.

Finally, we examined whether PcauRAR can be exploited by EDCs by testing two organochloride pesticides, which have low water solubility, but are extremely persistent and particularly stable in soil [60]. Dieldrin was found in zooplankton and fishes from the Baltic Sea at concentrations between 15 and $170 \mathrm{ng} / \mathrm{g}$ lipid [55,56,58]; and $<0.2-9.9 \mathrm{~g}$ and $<0.15-0.8 \mathrm{~g}$ of dieldrin and endrin, respectively, were found per $g$ of sludge and sediments [57]. Significantly, these compounds are known to disrupt the endocrine system in humans through the modulation of RA signalling pathways [34,54]. In agreement, 
with the study conducted in molluscs [24], we show that the tested pesticides were not able to activate PcauRAR and consequently induce gene transcription. To understand the mechanisms of action of EDCs in invertebrate lineages is problematic given the paucity of appropriate comparative approaches. For instance, of the various Ecdysozoa groups, only three (Insecta, Crustacea and Nematoda) have been thoroughly examined from an endocrinology standpoint [32]. Moreover, several aquatic pollutants have been reported to retard growth and moulting and influence mortality in crustaceans [61-63] and to affect growth, reproduction, life span and gene expression in nematodes [64,65]. Importantly, one of the clearest examples of endocrine disruption - imposex development in gastropods upon exposure to organotins, was shown to result from a specific interaction with the highly conserved NR RXR [66-68]. Moreover, the inclusion of comparative approaches and evolutionary thinking has highlighted the conserved and divergent biological responses to xenobiotics mediated by NRs (e.g., PPAR [69], PXR [70], ER [71]). Thus, defining the gene complement of NRs, their set of "natural" ligands and in vivo functions across the diversity of protostome phyla is fundamental to comprehend the impacts of EDCs in the Anthropocene epoch [72].

\section{Conclusions}

We provide here the first characterization of an Ecdysozoa RAR. Our findings, contribute to further clarify the early evolution of the RA gene module in Metazoa, supporting the hypothesis that RAR emerged as RA low-affinity sensor in the Bilateria, with the high-affinity RA binding profile acquired in chordates.

Supplementary Materials: The following are available online at http://www.mdpi.com/2073-4425/10/12/985/s1, Video S1: Live specimens of $P$. caudatus; Figure S1: Analysis of the interaction between priapulid and human RAR-LBD-GAL4 with RXR-LBD-VP16 partner through a mammalian two-hybrid assay in COS-1 cells with no ligands. Table S1: List of primers used to isolate P. caudatus RAR and RXR genes, Table S2: List of sequences used for phylogenetic reconstruction of $T R, R A R, P P A R$ and $R X R$ genes and corresponding accession numbers, Table S3: List of primers used to amplify hinge region to LBD of RAR and RXR to be cloned into pBIND or pACT expression vectors.

Author Contributions: Conceptualization, L.F.C.C.; methodology, E.S.S.F., Y.H., R.R., T.N., M.M.S. and L.F.C.C.; validation, E.S.S.F., Y.H., Y.K., R.R., T.N., M.M.S. and L.F.C.C.; formal analysis, E.S.S.F., Y.H., Y.K., R.R., J.N.F., T.N., M.M.S. and L.F.C.C.; investigation, E.S.S.F., Y.H., Y.K., R.R., J.N.F., T.N., M.M.S. and L.F.C.C.; resources, J.N.F., T.N., M.M.S. and L.F.C.C.; data curation, E.F., Y.H., R.R., T.N., M.M.S. and L.F.C.C.; writing-original draft preparation, E.S.S.F., Y.H. and L.F.C.C; writing-review and editing, E.S.S.F., Y.H., Y.K., R.R, T.N., M.M.S. and L.F.C.C.; supervision, T.N., M.M.S. and L.F.C.C.; project administration, L.F.C.C.; funding acquisition, T.N., M.M.S. and L.F.C.C.

Funding: This research was funded by COMPETE 2020, Portugal 2020 and the European Union through the ERDF, grant number 031342, and a Grant-in-Aid for Scientific Research (C) from the Ministry of Education, Culture, Sports, Science and Technology (Japan), grant number 18K06737 and by FCT through national funds. A PhD grant awarded to Elza Fonseca (SFRH/BD/100262/2014) was funded by the FCT.

Acknowledgments: We acknowledge Richard K. Wilson, Director, and the McDonnell Genome Institute, Washington University School of Medicine for the P. caudatus genome assembly 5.0.

Conflicts of Interest: The authors declare no conflict of interest.

\section{References}

1. Ross, S.; McCaffery, P.; Drager, U.; De Luca, L. Retinoids in embryonal development. Physiol. Rev. 2000, 80, 1021-1054. [CrossRef] [PubMed]

2. Samarut, E.; Rochette-Egly, C. Nuclear retinoic acid receptors: Conductors of the retinoic acid symphony during development. Mol. Cell Endocrinol. 2012, 348, 348-360. [CrossRef] [PubMed]

3. Niederreither, K.; Dollé, P. Retinoic acid in development: Towards an integrated view. Nat. Rev. Genet. 2008, 9, 541-553. [CrossRef] [PubMed]

4. Escriva, H.; Holland, N.; Gronemeyer, H.; Laudet, V.; Holland, L. The retinoic acid signaling pathway regulates anterior/posterior patterning in the nerve cord and pharynx of amphioxus, a chordate lacking neural crest. Development 2002, 129, 2905-2916. [PubMed] 
5. Schubert, M.; Holland, N.; Escriva, H.; Holland, L.; Laudet, V. Retinoic acid influences anteroposterior positioning of epidermal sensory neurons and their gene expression in a developing chordate (amphioxus). Proc. Natl. Acad. Sci. USA 2004, 101, 10320-10325. [CrossRef] [PubMed]

6. Cunningham, T.; Duester, G. Mechanisms of retinoic acid signalling and its roles in organ and limb development. Nat. Rev. Mol. Cell Biol. 2015, 16, 110-123. [CrossRef] [PubMed]

7. Maden, M.; Hind, M. Retinoic acid, a regeneration-inducing molecule. Dev. Dyn. 2003, 226, $237-244$. [CrossRef]

8. Bertrand, S.; Thisse, B.; Tavares, R.; Sachs, L.; Chaumot, A.; Bardet, P.; Escriva, H.; Duffraisse, M.; Marchand, O.; Safi, R.; et al. Unexpected novel relational links uncovered by extensive developmental profiling of nuclear receptor expression. PLoS Genet. 2007, 3, e188. [CrossRef]

9. Cvekl, A.; Wang, W. Retinoic acid signaling in mammalian eye development. Exp. Eye Res. 2009, 89, $280-291$. [CrossRef]

10. Albalat, R. The retinoic acid machinery in invertebrates: Ancestral elements and vertebrate innovations. Mol. Cell Endocrinol. 2009, 313, 23-35. [CrossRef]

11. Rochette-Egly, C.; Germain, P. Dynamic and combinatorial control of gene expression by nuclear retinoic acid receptors (RARs). Nucl. Recep. Signal. 2009, 7, e005. [CrossRef] [PubMed]

12. Germain, P.; Staels, B.; Dacquet, C.; Spedding, M.; Laudet, V. Overview of nomenclature of nuclear receptors. Pharm. Rev. 2006, 58, 685-704. [CrossRef] [PubMed]

13. Germain, P.; Altucci, L.; Bourguet, W.; Rochette-Egly, C.; Gronemeyer, H. Nuclear receptor superfamily: Principles of signaling. Pure Appl. Chem. 2003, 75, 1619-1664. [CrossRef]

14. Chatagnon, A.; Veber, P.; Morin, V.; Bedo, J.; Triqueneaux, G.; Sémon, M.; Laudet, V.; D’Alché-Buc, F.; Benoit, G. RAR/RXR binding dynamics distinguish pluripotency from differentiation associated cis-regulatory elements. Nucleic Acids Res. 2015, 43, 4833-4854. [CrossRef] [PubMed]

15. Albalat, R.; Cañestro, C. Identification of Aldh1a, Cyp26 and RAR orthologs in protostomes pushes back the retinoic acid genetic machinery in evolutionary time to the bilaterian ancestor. Chem. Biol. Interact. 2009, 178, 188-196. [CrossRef] [PubMed]

16. Cañestro, C.; Postlethwait, J.; Gonzalez-Duarte, R.; Albalat, R. Is retinoic acid genetic machinery a chordate innovation? Evol. Dev. 2006, 8, 394-406. [CrossRef] [PubMed]

17. Howard-Ashby, M.; Materna, S.; Brown, C.; Chen, L.; Cameron, R.; Davidson, E. Gene families encoding transcription factors expressed in early development of Strongylocentrotus purpuratus. Dev. Biol. 2006, 300, 90-107. [CrossRef]

18. Marlétaz, F.; Holland, L.; Laudet, V.; Schubert, M. Retinoic acid signaling and the evolution of chordates. Int. J. Biol. Sci. 2006, 2, 38-47. [CrossRef]

19. Ollikainen, N.; Chansawangbhuwana, C.; Baker, M. Evolution of the thyroid hormone, retinoic acid, ecdysone and liver $\mathrm{X}$ receptors. Integr. Comp. Biol. 2006, 46, 815-826. [CrossRef]

20. Simões-Costa, M.; Azambuja, A.; Xavier-Neto, J. The search for non-chordate retinoic acid signaling: Lessons from chordates. J. Exp. Zool. B Mol. Dev. Evol. 2008, 310, 54-72. [CrossRef]

21. Campo-Paysaa, F.; Marlétaz, F.; Laudet, V.; Schubert, M. Retinoic acid signaling in development: Tissue-specific functions and evolutionary origins. Genesis 2008, 46, 640-656. [CrossRef] [PubMed]

22. Gutierrez-Mazariegos, J.; Nadendla, E.; Lima, D.; Pierzchalski, K.; Jones, J.; Kane, M.; Nishikawa, J.-I.; Hiromori, Y.; Nakanishi, T.; Santos, M.; et al. A mollusk retinoic acid receptor (RAR) ortholog sheds light on the evolution of ligand binding. Endocrinology 2014, 155, 4275-4286. [CrossRef] [PubMed]

23. Urushitani, H.; Katsu, Y.; Ohta, Y.; Shiraishi, H.; Iguchi, T.; Horiguchi, T. Cloning and characterization of the retinoic acid receptor-like protein in the rock shell, Thais clavigera. Aquat. Toxicol. 2013, 142-143, 403-413. [CrossRef] [PubMed]

24. André, A.; Ruivo, R.; Fonseca, E.; Froufe, E.; Castro, L.; Santos, M. The retinoic acid receptor (RAR) in molluscs: Function, evolution and endocrine disruption insights. Aquat. Toxicol. 2019, 208, 80-89. [CrossRef] [PubMed]

25. Handberg-Thorsager, M.; Gutierrez-Mazariegos, J.; Arold, S.; Kumar Nadendla, E.; Bertucci, P.; Germain, P.; Tomançak, P.; Pierzchalski, K.; Jones, J.; Albalat, R.; et al. The ancestral retinoic acid receptor was a low-affinity sensor triggering neuronal differentiation. Sci. Adv. 2018, 4, eaao1261. [CrossRef] [PubMed]

26. Janesick, A.; Wu, S.; Blumberg, B. Retinoic acid signaling and neuronal differentiation. Cell Mol. Life Sci. 2015, 72, 1559-1576. [CrossRef] 
27. Castro, L.; Santos, M. To bind or not to bind: The taxonomic scope of nuclear receptor mediated endocrine disruption in invertebrate phyla. Environiron. Sci. Technol. 2014, 48, 5361-5363. [CrossRef]

28. Capitão, A.; Lyssimachou, A.; Castro, L.; Santos, M. Obesogens in the aquatic Environironment: An evolutionary and toxicological perspective. Environ. Int. 2017, 106, 153-169.

29. Balaguer, P.; Delfosse, V.; Grimaldi, M.; Bourguet, W. Structural and functional evidences for the interactions between nuclear hormone receptors and endocrine disruptors at low doses. C. R. Biol. 2017, 340, 414-420. [CrossRef]

30. Keay, J.; Thornton, J. Hormone-activated estrogen receptors in annelid invertebrates: Implications for evolution and endocrine disruption. Endocrinology 2009, 150, 1731-1738. [CrossRef]

31. Vogeler, S.; Galloway, T.; Isupov, M.; Bean, T. Cloning retinoid and peroxisome proliferator-activated nuclear receptors of the Pacific oyster and in silico binding to Environironmental chemicals. PLoS ONE 2017, 12, e0176024. [CrossRef] [PubMed]

32. Katsiadaki, I. Are marine invertebrates really at risk from endocrine-disrupting chemicals? Curr. Opin. Environ. Sci. Health 2019, 11, 37-42. [CrossRef]

33. Scott, A. Is there any value in measuring vertebrate steroids in invertebrates? Gen. Comp. Endocrinol. 2018, 265, 77-82. [CrossRef] [PubMed]

34. Lemaire, G.; Balaguer, P.; Michel, S.; Rahmani, R. Activation of retinoic acid receptor-dependent transcription by organochlorine pesticides. Toxicol. Appl. Pharm. 2005, 202, 38-49. [CrossRef]

35. Sansom, R. Preservation and phylogeny of Cambrian ecdysozoans tested by experimental decay of Priapulus. Sci. Rep. 2016, 6, 32817. [CrossRef]

36. Webster, B.; Copley, R.; Jenner, R.; Mackenzie-Dodds, J.; Bourlat, S.; Rota-Stabelli, O.; Littlewood, D.; Telford, M. Mitogenomics and phylogenomics reveal priapulid worms as extant models of the ancestral Ecdysozoan. Evol. Dev. 2006, 8, 502-510. [CrossRef]

37. Wills, M.; Gerber, S.; Ruta, M.; Hughes, M. The disparity of priapulid, archaeopriapulid and palaeoscolecid worms in the light of new data. J. Evol. Biol. 2012, 25, 2056-2076. [CrossRef]

38. Katoh, K.; Toh, H. Parallelization of the MAFFT multiple sequence alignment program. Bioinformatics 2010, 26, 1899-1900. [CrossRef]

39. Renaud, J.; Rochel, N.; Ruff, M.; Vivat, V.; Chambon, P.; Gronemeyer, H.; Moras, D. Crystal structure of the RAR- $\gamma$ ligand-binding domain bound to all-trans retinoic acid. Nature 1995, 378, 681-689. [CrossRef]

40. Hisata, K.; Fujiwara, S.; Tsuchida, Y.; Ohashi, M.; Kawamura, K. Expression and function of a retinoic acid receptor in budding ascidians. Dev. Genes Evol. 1998, 208, 537-546. [CrossRef]

41. Gesto, M.; Ruivo, R.; Páscoa, I.; André, A.; Castro, L.; Santos, M. Retinoid level dynamics during gonad recycling in the limpet Patella vulgata. Gen. Comp. Endocrinol. 2016, 225, 142-148. [CrossRef] [PubMed]

42. Escriva, H.; Bertrand, S.; Germain, P.; Robinson-Rechavi, M.; Umbhauer, M.; Cartry, J.; Duffraisse, M.; Holland, L.; Gronemeyer, H.; Laudet, V. Neofunctionalization in vertebrates: The example of retinoic acid receptors. PLoS Genet. 2006, 2, e102. [CrossRef] [PubMed]

43. Guindon, S.; Dufayard, J.; Lefort, V.; Anisimova, M.; Hordijk, W.; Gascuel, O. New Algorithms and Methods to Estimate Maximum-Likelihood Phylogenies: Assessing the Performance of PhyML 3.0. Syst. Biol. 2010, 59, 307-321. [CrossRef] [PubMed]

44. Duffy, J. GAL4 system in Drosophila: A fly geneticist's Swiss army knife. Genesis 2002, 34, 1-15. [CrossRef] [PubMed]

45. Hagmann, M.; Georgiev, O.; Schaffner, W. The VP16 paradox: Herpes simplex virus VP16 contains a long-range activation domain but within the natural multiprotein complex activates only from promoter-proximal positions. J. Virol. 1997, 71, 5952-5962. [PubMed]

46. Nakanishi, T.; Nishikawa, J.; Hiromori, Y.; Yokoyama, H.; Koyanagi, M.; Takasuga, S.; Ishizaki, J.; Watanabe, M.; Isa, S.; Utoguchi, N.; et al. Trialkyltin compounds bind retinoid X receptor to alter human placental endocrine functions. Mol. Endocrinol. 2005, 19, 2502-2516. [CrossRef]

47. Hiromori, Y.; Nishikawa, J.; Yoshida, I.; Nagase, H.; Nakanishi, T. Structure-dependent activation of peroxisome proliferator-activated receptor (PPAR) $\gamma$ by organotin compounds. Chem. Biol. Interact. 2009, 180, 238-244. [CrossRef]

48. Hiromori, Y.; Ido, A.; Aoki, A.; Kimura, T.; Nagase, H.; Nakanishi, T. Ligand activity of group 15 compounds possessing triphenyl substituent for the RXR and PPAR $\gamma$ nuclear receptors. Biol. Pharm. Bull. 2016, 39, 1596-1603. [CrossRef] 
49. Aranda, A.; Pascual, A. Nuclear hormone receptors and gene expression. Physiol. Rev. 2001, 81, 1269-1304. [CrossRef]

50. Chambon, P. The nuclear receptor superfamily: A personal retrospect on the first two decades. Mol. Endocrinol. 2005, 19, 1418-1428. [CrossRef]

51. Bertrand, S.; Brunet, F.; Escriva, H.; Parmentier, G.; Laudet, V.; Robinson-Rechavi, M. Evolutionary genomics of nuclear receptors: From twenty-five ancestral genes to derived endocrine systems. Mol. Biol. Evol. 2004, 21, 1923-1937. [PubMed]

52. Darbre, P. Endocrine Disruption and Human Health. Overview of EDCs and Human Health Which Sets the Bigger Picture; Academic: New York, NY, USA, 2015.

53. Laudet, V.; Gronemeyer, H. The Nuclear Receptors Factsbook; Academic Press: London, UK, 2002; ISBN 0-12-437735-1.

54. Kamata, R.; Shiraishi, F.; Nishikawa, J.; Yonemoto, J.; Shiraishi, H. Screening and detection of the in vitro agonistic activity of xenobiotics on the retinoic acid receptor. Toxicol. Vitr. 2008, 22, 1050-1061.

55. Strandberg, B.; Strandberg, L.; van Bavel, B.; Bergqvist, P.; Broman, D.; Falandysz, J.; Näf, C.; Papakosta, O.; Rolff, C.; Rappe, C. Concentrations and spatial variations of cyclodienes and other organochlorines in herring and perch from the Baltic Sea. Sci. Total Environ. 1998, 215, 69-83. [PubMed]

56. Strandberg, B.; Bandh, C.; van Bavel, B.; Bergqvist, P.; Broman, D.; Näf, C.; Pettersen, H.; Rappe, C. Concentrations, biomagnification and spatial variation of organochlorine compounds in a pelagic food web in the northern part of the Baltic Sea. Sci. Total Environ. 1998, 217, 143-154. [CrossRef]

57. Falandysz, J.; Strandberg, B. Persistent Organochlorine Compounds in Sludge and Sediments from the Gdańsk Region, Baltic Sea. Pol. J. Environ. Stud. 2004, 13, 133-138.

58. Schubert, S.; Keddig, N.; Gerwinski, W.; Neukirchen, J.; Kammann, U.; Haarich, M.; Hanel, R.; Theobald, N. Persistent organic pollutants in Baltic herring (Clupea harengus)-an aspect of gender. Environ. Monit. Assess. 2016, 188, 368. [CrossRef]

59. Telford, M.; Bourlat, S.; Economou, A.; Papillon, D.; Rota-Stabelli, O. The evolution of the Ecdysozoa. Philos. Trans. R. Soc. Lond. B Biol. Sci. 2008, 363, 1529-1537. [CrossRef]

60. Garnaga-Budre, G. Integrated assessment of pollution in the Baltic Sea. Ekologija 2012, 58, 331-355.

61. Hosamani, N.; Reddy, S.; Reddy, R. Crustacean Molting: Regulation and Effects of Environironmental Toxicants. J. Mar. Sci. Res. Dev. 2017, 7, 236. [CrossRef]

62. Lagadic, L.; Katsiadaki, I.; Biever, R.; Guiney, P.; Karouna-Renier, N.; Schwarz, T.; Meador, J. Tributyltin: Advancing the Science on Assessing Endocrine Disruption with an Unconventional Endocrine-Disrupting Compound. Rev. Environ. Contam. Toxicol. 2018, 245, 65-127.

63. Vogt, É.; Model, J.; Vinagre, A. Effects of Organotins on Crustaceans: Update and Perspectives. Front. Endocrinol. 2018, 9, 65. [CrossRef] [PubMed]

64. Höss, S.; Weltje, L. Endocrine disruption in nematodes: Effects and mechanisms. Ecotoxicology 2007, 16, 15-28. [CrossRef] [PubMed]

65. Chen, H.; Wang, C.; Li, H.; Ma, R.; Yu, Z.; Li, L.; Xiang, M.; Chen, X.; Hua, X.; Yu, Y. A review of toxicity induced by persistent organic pollutants (POPs) and endocrine-disrupting chemicals (EDCs) in the nematode Caenorhabditis elegans. J. Environ. Manag. 2019, 237, 519-525. [CrossRef] [PubMed]

66. Castro, L.; Lima, D.; Machado, A.; Melo, C.; Hiromori, Y.; Nishikawa, J.; Nakanishi, T.; Reis-Henriques, M.; Santos, M. Imposex induction is mediated through the Retinoid $X$ receptor signalling pathway in the neogastropod Nucella lapillus. Aquat. Toxicol. 2007, 85, 57-66. [CrossRef]

67. Lima, D.; Reis-Henriques, M.; Silva, R.; Santos, A.; Castro, L.; Santos, M. Tributyltin-induced imposex in marine gastropods involves tissue-specific modulation of the retinoid X receptor. Aquat. Toxicol. 2011, 101, 221-227. [CrossRef]

68. Stange, D.; Sieratowicz, A.; Oehlmann, J. Imposex development in Nucella lapillus-Evidence for the involvement of retinoid $X$ receptor and androgen signalling pathways in vivo. Aquat. Toxicol. 2012, 106-107, 20-24. [CrossRef]

69. Capitão, A.; Lopes-Marques, M.; Ishii, Y.; Ruivo, R.; Fonseca, E.; Páscoa, I.; Jorge, R.; Barbosa, M.; Hiromori, Y.; Miyagi, T.; et al. Evolutionary Exploitation of Vertebrate Peroxisome Proliferator-Activated Receptor $\gamma$ by Organotins. Environ. Sci. Technol. 2018, 52, 13951-13959. 
70. Fonseca, E.; Ruv, R.; Machado, A.M.; Conrado, F.; Tay, B.H.; Venkatesh, B.; Santos, M.M.; Castro, L.F.C. Evolutionary Plasticity in Detoxification Gene Modules: The Preservation and Loss of the Pregnane $X$ Receptor in Chondrichthyes Lineages. Int. J. Mol. Sci. 2019, 10, 2331. [CrossRef]

71. Paris, M.; Pettersson, K.; Schubert, M.; Bertrand, S.; Pongratz, I.; Escriva, H.; Laudet, V. An amphioxus orthologue of the estrogen receptor that does not bind estradiol: Insights into estrogen receptor evolution. BMC Evol. Biol. 2008, 8, 219. [CrossRef]

72. Santos, M.M.; Ruivo, R.; Capitão, A.; Fonseca, E.; Castro, L.F.C. Identifying the gaps: Resources and perspectives on the use of nuclear receptor based-assays to improve hazard assessment of emerging contaminants. J. Hazard. Mater. 2018, 358, 508-511. [CrossRef]

(C) 2019 by the authors. Licensee MDPI, Basel, Switzerland. This article is an open access article distributed under the terms and conditions of the Creative Commons Attribution (CC BY) license (http://creativecommons.org/licenses/by/4.0/). 